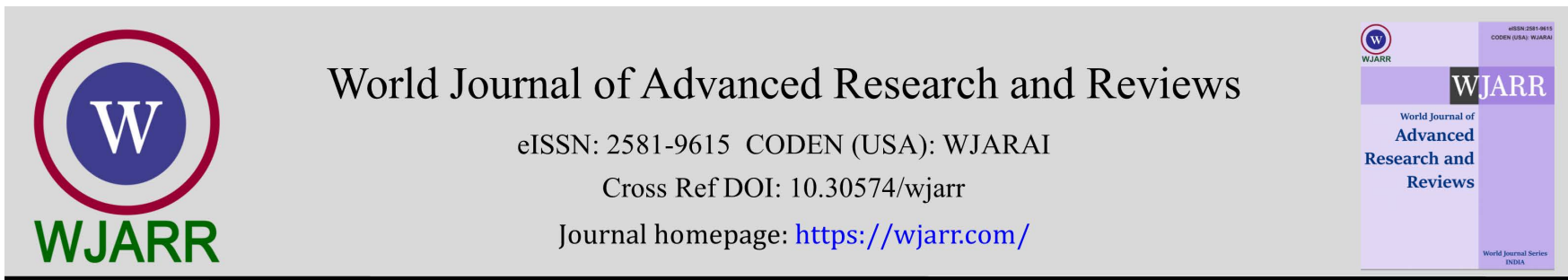

(RESEARCH ARTiClE)

\title{
Species diversity of fishes in relation to physicochemical status of the Yamuna at Kalpi (UP) India
}

\author{
Manoj Kumar Shukla* \\ Chhatrasal Government Post Graduate College, Panna, Madhya Pradesh, India.
}

World Journal of Advanced Research and Reviews, 2021, 10(02), 206-213

Publication history: Received on 07 April 2021; revised on 11 May 2021; accepted on 14 May 2021

Article DOI: https://doi.org/10.30574/wjarr.2021.10.2.0217

\begin{abstract}
Fishes are the primary indicators of pollution of water bodies because they are conspicuous and changes in physicochemical characteristics of water affects their growth and reproductive multiplication rate. The study reveals the species diversity of fishes in relation to physicochemical status of the Yamuna river at Kalpi stretch. Four sampling station were selected on the Yamuna river for sample collection to analysis species diversity of fishes in relation to physicochemical status of studied river. Sampling for fish fauna and physicochemical analysis of water was done simultaneously for one year. The collected samples were analysed for selected physicochemical parameters and collected fishes was identified in the same time. Selected physicochemical parameters were Water Temperature (W.T.), pH, Conductivity, Turbidity, Total Dissolved Solids (T.D.S.), Total Hardness (TH), Total Alkalinity (T.A.), Chloride (Cl), Sulphate $\left(\mathrm{SO}_{4}\right)$, Phosphate $\left(\mathrm{PO}_{4}\right)$, Nitrate $\left(\mathrm{NO}_{3}\right)$, Dissolved Oxygen (D.O.), Biochemical Oxygen Demand (B.O.D.) and Chemical Oxygen Demand (C.O.D.). Mostly physicochemical parameters were found suitable for survival and growth of fish fauna. Yamuna river at Kalpi stretch have high potential for fish production which is not utilize till now.
\end{abstract}

Keywords: Fish diversity; Kalpi; Physicochemical status; Yamuna

\section{Introduction}

Natural or manmade pollution in the water changes Temperature, pH, Turbidity, Total Dissolved Solids, Dissolved Oxygen and B.O.D. which in turn affects the fish population. Fishes are the primary indicators of pollution of rivers because they are conspicuous. Changes in physicochemical characteristics of water affects the growth and reproductive multiplication rate of fishes, which are likely to very among different species. Due to requirement of food for fast growing population in India, at least two-fold increment in fish production is called for within next few years. Now a day riverine fisheries have declined. So, it become necessary to study about fish fauna, their food ecology and their limnological status for better production of fish culture. Considering the importance of fresh water resources in inland fishery, number of studies have been conducted $[1,2,3,4,5,6,7,8,9$ and10]. The present study reveals the species diversity of fishes in relation to physicochemical status of the Yamuna river at Kalpi stretch in which it is try to investigate the suitability of physicochemical condition of studied river water for fish growth and reproduction because Yamuna river at Kalpi stretch have high potential for fish production which is not utilize till now.

Objectives of the study is to assess the physicochemical characteristics of river Yamuna along with collection and identification of fish fauna and analysis the impacts of physicochemical parameters of this water on growth and reproduction of fish fauna.

\footnotetext{
${ }^{*}$ Corresponding author: Manoj Kumar Shukla

Department of Botany, Chhatrasal Govt. PG College, Panna, MP, India.

Copyright (C) 2021 Author(s) retain the copyright of this article. This article is published under the terms of the Creative Commons Attribution Liscense 4.0.
} 


\section{Material and methods}

Kalpi is a historical city of district Jalaun of Uttar Pradesh located in between Jhansi and Kanpur on NH-25 lies to the south east bank of Yamuna and falls under $26^{0} 7^{\prime} 14^{\prime \prime} \mathrm{N}$ latitude to $79^{\circ} 44^{\prime} 59^{\prime \prime}$ E longitude with an average elevation of 112 meters. $5 \mathrm{Km}$. length of Yamuna at Kalpi from in front of Vyas mandir (U/S) to Raid drain opening (D/S) is under the study programme (Fig. - 1). Four sampling stations named as S1- in front of Vyas Mandir, S2- Kila Ghat, S3- Peela Ghat and S4- just after Raid drain opening were selected for the sampling purpose. The samples were collected monthly till one year (October 2013 to September 2014) from selected sampling stations in sterilized plastic bottles. For physicochemical parameters samples were analysed according to the standard methods [11 \& 12]. Water temperature was measured by thermometer and $\mathrm{pH}$ was measured by pen $\mathrm{pH}$ meter at sampling site. Other parameters like Cond., Turb., T.D.S., T.H., T.A., Cl, $\mathrm{SO}_{4}, \mathrm{PO}_{4}, \mathrm{NO}_{3}$, D.O., B.O.D. and C.O.D. were determined in the laboratory. Fishes were collected by monthly sampling using nets of various mesh size from the selected sampling sites. The identification of fish fauna was also carried out simultaneously with the help of standard books and monographs [13 \& 14].

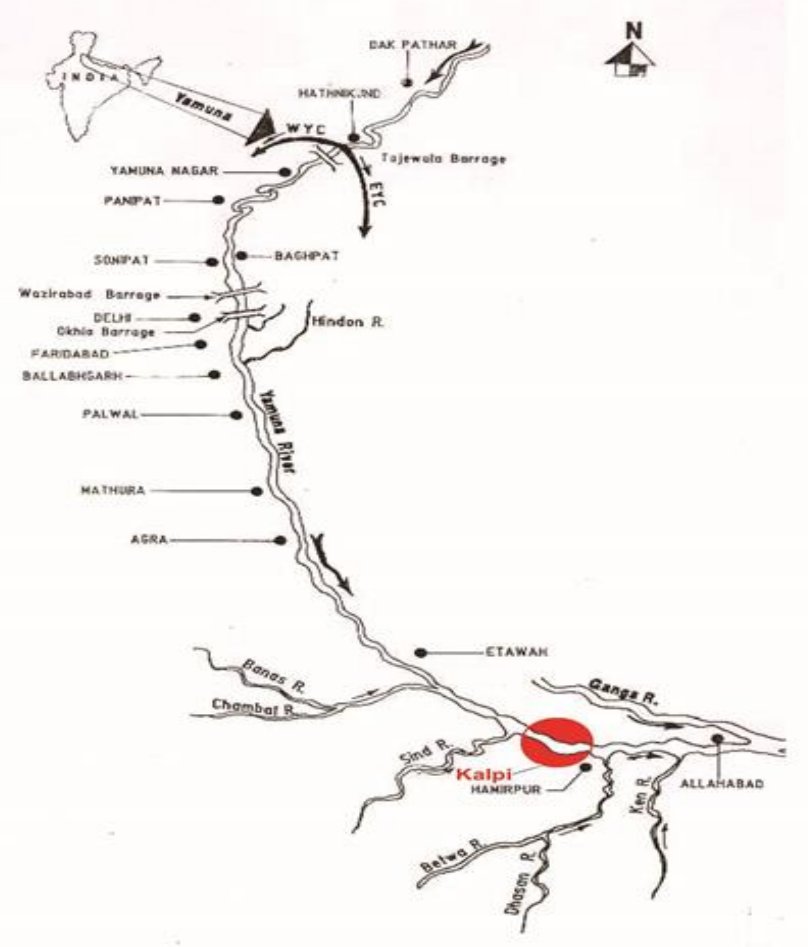

Figure 1 Location of study area (Kalpi) in map of the Yamuna river [Source: 15].

\section{Results and discussion}

The observed physicochemical parameters were tabulated and analysed to understand the physicochemical characteristics of water. Simultaneously the fish fauna was also observed and identified and efforts were made to understand the co-relation between them.

\subsection{Physicochemical Parameters}

The recorded physicochemical parameters of 4 sampling sites were tabulated and analysed (Table no-1). Water Temperature (W.T.) was recorded in range of $15.5^{\circ} \mathrm{C}$ to $31.5^{\circ} \mathrm{C}$ and average WT was $25.38^{\circ} \mathrm{C}$. Fishes required moderate temperature for their best growth and reproduction. Temperature was found suitable for the survival and growth of fish fauna [16]. The $\mathrm{pH}$ value was in range from 7.60 to 8.70 and average value was 8.28. pH of Yamuna river was alkaline in nature, which is a good indicator for survival of fishes [17]. Conductivity was recorded in the range of $330 \mu \mathrm{S} / \mathrm{cm}$ to $1060 \mu \mathrm{S} / \mathrm{cm}$ during study period. The average value of Conductivity was $601.25 \mu \mathrm{S} / \mathrm{cm}$. The value of Turbidity was fluctuating from 26.0 to 200 NTU and average was 83.58 NTU. Turbidity of the Yamuna water was under the limit in most of the time of study period for fish growth and survival. Total Dissolved Solids (T.D.S.) was in range from 458 to $675 \mathrm{mg} / \mathrm{l}$. while average value was $564.58 \mathrm{mg} / \mathrm{l}$. Recorded Total Hardness (TH) of the Yamuna water was in the range of $84.5 \mathrm{mg} / \mathrm{l}$ to $148.9 \mathrm{mg} / \mathrm{l}$ while average was $111.48 \mathrm{mg} / \mathrm{l}$. 
Table 1 Physicochemical Parameters of Yamuna river at Kalpi. [Source: 9]

\begin{tabular}{|c|c|c|c|c|c|c|c|c|c|c|c|c|c|c|c|}
\hline \multicolumn{2}{|c|}{$\begin{array}{l}\text { Period- } \\
2013 \text { to } \text { Oct. } \\
2014\end{array}$} & \multicolumn{14}{|c|}{ Physicochemical Parameters } \\
\hline Season & Mon & $\begin{array}{l}\text { Wt. } \\
\left({ }^{\circ} \mathrm{C}\right)\end{array}$ & $\mathrm{pH}$ & $\begin{array}{l}\text { Con. } \\
\mu \mathrm{S} / \mathrm{Cm}\end{array}$ & $\begin{array}{l}\text { Tur. } \\
\text { NTU }\end{array}$ & $\begin{array}{l}\text { T.D.S } \\
\text { mg/L }\end{array}$ & $\begin{array}{l}\text { T.H. } \\
\text { mg/L }\end{array}$ & $\begin{array}{l}\text { T.A. } \\
\text { mg/L }\end{array}$ & $\begin{array}{l}\mathrm{Cl} \\
\mathrm{mg} / \mathrm{L}\end{array}$ & $\begin{array}{l}\mathrm{SO}_{4} \\
\mathrm{mg} / \mathrm{L}\end{array}$ & $\begin{array}{l}\mathrm{PO}_{4} \\
\mathrm{mg} / \mathrm{L}\end{array}$ & $\begin{array}{l}\mathrm{NO}_{3} \\
\mathrm{mg} / \mathrm{L}\end{array}$ & $\begin{array}{l}\text { D.O. } \\
\text { mg/L }\end{array}$ & $\begin{array}{l}\text { BOD } \\
\mathrm{mg} / \mathrm{L}\end{array}$ & $\begin{array}{l}\text { COD } \\
\mathrm{mg} / \mathrm{L}\end{array}$ \\
\hline \multirow{4}{*}{$\begin{array}{l}\text { Winter } \\
\text { Season }\end{array}$} & Oct. & 28.0 & 7.85 & 490 & 76.0 & 545 & 96.2 & 139.62 & 16.98 & 25.0 & 0.65 & 0.95 & 7.25 & 6.9 & 24.0 \\
\hline & Nov & 22.0 & 8.03 & 520 & 86.0 & 508 & 94.5 & 104.87 & 17.75 & 21.50 & 0.58 & 0.65 & 7.6 & 6.3 & 20.2 \\
\hline & Dec. & 16.0 & 7.80 & 610 & 47.0 & 478 & 98.6 & 103.0 & 19.5 & 17.5 & 0.55 & 0.48 & 8.48 & 5.5 & 19.5 \\
\hline & Jan. & 15.5 & 7.60 & 550 & 53.5 & 458 & 115.0 & 91.5 & 25.85 & 23.40 & 0.52 & 0.45 & 8.53 & 7.35 & 23.95 \\
\hline \multirow{4}{*}{$\begin{array}{l}\text { Summer } \\
\text { Season }\end{array}$} & Feb. & 19.8 & 8.20 & 600 & 26.0 & 464 & 125.0 & 187.5 & 29.30 & 24.50 & 0.56 & 0.58 & 8.35 & 7.8 & 23.0 \\
\hline & Mar & 24.5 & 8.34 & 640 & 38.0 & 467 & 121.0 & 211.5 & 35.40 & 24.70 & 0.58 & 0.85 & 7.85 & 8.6 & 24.5 \\
\hline & Apr. & 29.3 & 8.55 & 515 & 42.0 & 487 & 130.5 & 213.0 & 37.75 & 26.85 & 0.55 & 1.23 & 8.05 & 11.35 & 25.2 \\
\hline & May & 30.5 & 8.68 & 990 & 46.5 & 607 & 141.5 & 213.5 & 48.5 & 25.80 & 0.85 & 3.03 & 7.2 & 11.50 & 26.0 \\
\hline \multirow{4}{*}{$\begin{array}{l}\text { Rainy } \\
\text { Season }\end{array}$} & June & 31.5 & 8.70 & 1060 & 48.0 & 634 & 148.9 & 215.6 & 41.0 & 29.75 & 0.87 & 4.6 & 6.0 & 12.00 & 26.8 \\
\hline & Jul. & 28.5 & 8.48 & 550 & 160.0 & 640 & 95.0 & 214.5 & 18.5 & 17.89 & 0.95 & 1.25 & 6.5 & 6.5 & 13.50 \\
\hline & Aug & 30.0 & 8.60 & 330 & 200.0 & 675 & 84.5 & 210.75 & 14.5 & 11.05 & 1.74 & 0.38 & 6.65 & 5.45 & 10.85 \\
\hline & Sep. & 29.0 & 8.49 & 360 & 180.0 & 612 & 87.0 & 182.5 & 17.5 & 19.0 & 1.45 & 0.65 & 6.95 & 3.25 & 16.90 \\
\hline \multicolumn{2}{|l|}{ Minimum } & 15.5 & 7.60 & 330 & 26.0 & 458 & 84.5 & 91.5 & 14.5 & 11.05 & 0.52 & 0.38 & 6.0 & 3.25 & 10.85 \\
\hline \multicolumn{2}{|l|}{ Maximum } & 31.5 & 8.70 & 1060 & 200.0 & 675 & 148.9 & 215.6 & 48.5 & 29.75 & 1.74 & 4.6 & 8.53 & 12.00 & 26.80 \\
\hline \multicolumn{2}{|l|}{ Mean } & 25.38 & 8.28 & 601.25 & 83.58 & 564.58 & 111.48 & 173.92 & 26.88 & 22.25 & 0.82 & 1.26 & 7.45 & 7.71 & 21.2 \\
\hline
\end{tabular}

Where: W.T. = Water Temperature, Con. = Conductivity. Tur. = Turbidity, T.D.S. = Total Dissolved Solids, T.H. $=$ Total Hardness, T.A. = Total Alkalinity, $\mathrm{Cl}=\mathrm{Chloride}$ $\mathrm{SO}_{4}=$ Sulphate, $\mathrm{PO}_{4}=$ Phosphate, $\mathrm{NO}_{3}=$ Nitrate, D.O. = Dissolved Oxygen, B.O.D. = Biochemical Oxygen Demand, C.O.D. = Chemical Oxygen Demand. 
Total Alkalinity (T.A.) value was found in between $215.6 \mathrm{mg} / \mathrm{l}$ and $91.5 \mathrm{mg} / \mathrm{l}$ while average value was $173.92 \mathrm{mg} / \mathrm{l}$. T.A. of the Yamuna water was more than $100 \mathrm{mg} / \mathrm{l}$ in most of the time of study span thus it was suitable for fish culture [18]. Chloride (Cl) was varied from $14.5 \mathrm{mg} / \mathrm{l}$ to $48.5 \mathrm{mg} / \mathrm{l}$ and mean value was $26.88 \mathrm{mg} / \mathrm{l}$. Recorded Sulphate $\left(\mathrm{SO}_{4}\right) \mathrm{range}$ was $11.05 \mathrm{mg} / \mathrm{l}$ to $29.75 \mathrm{mg} / \mathrm{l}$. The average value of recorded sulphate was $22.25 \mathrm{mg} / \mathrm{l}$. Phosphate $\left(\mathrm{PO}_{4}\right)$ of Yamuna water was in the range of $0.52 \mathrm{mg} / \mathrm{l}$ to $1.74 \mathrm{mg} / \mathrm{l}$. Average value of recorded phosphate was $0.82 \mathrm{mg} / \mathrm{l}$. Nitrate $\left(\mathrm{NO} \mathrm{O}_{3}\right)$ was recorded in range of $0.38 \mathrm{mg} / \mathrm{l}$ to $4.60 \mathrm{mg} / \mathrm{l}$ and average value was $1.26 \mathrm{mg} / \mathrm{l}$. The value of Dissolved Oxygen (D.0.) was ranged from 6.00 to $8.53 \mathrm{mg} /$ l. Average value of recorded D.0. was $7.45 \mathrm{mg} / \mathrm{l}$. During study period, recorded D.0. range in the Yamuna water was good for fish culture. Biochemical Oxygen Demand (B.O.D.) was recorded in between $3.25 \mathrm{mg} / \mathrm{l}$ to $12.00 \mathrm{mg} / \mathrm{l}$ and average value of $7.71 \mathrm{mg} / \mathrm{l}$. Recorded B.O.D. was also satisfactory for fish growth and survival in most of the time of study period. Chemical Oxygen Demand (C.O.D.) of the Yamuna water was varied in between $10.85 \mathrm{mg} / \mathrm{l}$ to $26.80 \mathrm{mg} / \mathrm{l}$. The average value of recorded C.O.D. was $21.2 \mathrm{mg} / \mathrm{l}$. It was also under the limit for fish growth and reproduction.

\subsection{Fishes}

29 species of fishes have been recorded and identified in present study in Kalpi stretch of the Yamuna (Table no- 2 and photo no. 1- 23). 58 taxa of fishes in river Yamuna at Chilla (Banda, U.P.) reported in his study [19]. IIT $_{(\mathrm{s})}$, have been recorded 67 species, 51 genus belonging to 23 families in Auraiyya to Allahabad stretch of Yamuna river [20].

Table 2: Recorded and identified Fish species from the river Yamuna at Kalpi stretch. [Source: 9]

\begin{tabular}{|c|c|c|c|c|}
\hline & Fish & Species & Local Name & Family \\
\hline 1. & Anabas & testudineus & Kabai/Jalebi & Anabantidae \\
\hline 2. & Barilius & barna & Ghilra & Cyprinidae \\
\hline 3. & Catla & catla & Catla/Bosa/Bhakur & Cyprinidae \\
\hline 4. & Chagunius & chagunio & Chhagau & Cyprinidae \\
\hline 5. & $\begin{array}{l}\text { Channa } \\
\text { Channa } \\
\text { Channa }\end{array}$ & $\begin{array}{l}\text { gachua } \\
\text { marulius } \\
\text { punctatus }\end{array}$ & $\begin{array}{l}\text { Girai/Bilaua } \\
\text { Padam saur } \\
\text { Sauri/Gurrie }\end{array}$ & $\begin{array}{l}\text { Channidae } \\
\text { Channidae } \\
\text { Channidae }\end{array}$ \\
\hline 6. & $\begin{array}{l}\text { Cirrhinus } \\
\text { Cirrhinus }\end{array}$ & $\begin{array}{l}\text { mrigala } \\
\text { reba }\end{array}$ & $\begin{array}{l}\text { Nain/Mrigla } \\
\text { Raiya/Lahkariya }\end{array}$ & $\begin{array}{l}\text { Cyprinidae } \\
\text { Cyprinidae }\end{array}$ \\
\hline 7. & Clarias & batrachus & Mangur & Clariidae \\
\hline 8. & Cyprinus & carpio & Common Carp & Cyprinidae \\
\hline 9. & Esomus & danricus & Anjiara & Cyprinidae \\
\hline 10. & Eutropiichthys & vacha & Bachuwa & Schilbeidae \\
\hline 11. & Heteropneustes & fossilis & Singhi & Heteropneustidae \\
\hline 12. & Hypopthalmicthys & molitrix & Silver Carp & Cyprinidae \\
\hline 13. & $\begin{array}{l}\text { Labeo } \\
\text { Labeo } \\
\text { Labeo } \\
\text { Labeo } \\
\end{array}$ & $\begin{array}{l}\text { bata } \\
\text { calbasu } \\
\text { gonius } \\
\text { rohita } \\
\end{array}$ & $\begin{array}{l}\text { Bata } \\
\text { Karaunt/Calbasu } \\
\text { Khursa } \\
\text { Rohu } \\
\end{array}$ & $\begin{array}{l}\text { Cyprinidae } \\
\text { Cyprinidae } \\
\text { Cyprinidae } \\
\text { Cyprinidae } \\
\end{array}$ \\
\hline 14. & Mastacembelus & armatus & Bam & Mastacembelidae \\
\hline 15. & $\begin{array}{l}\text { Mystus } \\
\text { Mystus } \\
\end{array}$ & $\begin{array}{l}\text { tengara } \\
\text { seenghala }\end{array}$ & $\begin{array}{l}\text { Chhota tengra } \\
\text { Tengan }\end{array}$ & $\begin{array}{l}\text { Bagridae } \\
\text { Bagridae }\end{array}$ \\
\hline 16. & $\begin{array}{l}\text { Notopterus } \\
\text { Notopterus }\end{array}$ & $\begin{array}{l}\text { chitala } \\
\text { notopterus }\end{array}$ & $\begin{array}{l}\text { Chital/Moya } \\
\text { Patra }\end{array}$ & $\begin{array}{l}\text { Notopteridae } \\
\text { Notopteridae }\end{array}$ \\
\hline 17. & Ompok & bimaculatus & Pabda/Jalkapoor & Siluridae \\
\hline 18. & Oxygaster & bacaila & Chelhua & Cyprinidae \\
\hline 19. & Puntius & sarana & Putiyah/Khabda & Cyprinidae \\
\hline 20. & Rita & rita & Rita & Bagridae \\
\hline 21. & Wallago & attu & Parhin/Lanchi & Siluridae \\
\hline
\end{tabular}


Fish species like Anabas testudineus (Kabai/Jalebi), Catla catla (Catla), Channa marulius (Padam saur), C. punctatus (Saurri/Gurrie), Cirrhinus mrigala (Nain/Mrigla), Eutropiichthys vacha (Bachuwa), Labeo bata (Bata), L. calbasu (Karaunt/Calbasu), L. rohita (Rohu), Mastacembelus armatus (Bam), Mystus seenghala (Tengan), Notopterus chitala (Chital/Moya), N. notopterus (Patra), Oxygaster bacaila (Chelhua), Rita rita (Rita), Wallago attu (Parhin/Lanchi) were common to most common while Chagunius chagunio, Channa gachua, Clarias batrachus, Cyprinus carpio, Heteropneustes fossilis, Hypopthalmicthys molitrix and Mystus tengra were rare and Barilius barna, Cirrhinus reba, Esomus danricus, Labeo gonius, Ompok bimaculatus and Puntius sarana were very rare during study period. Fishes from the family Cyprinidae dominates the other variety of fish species.

\section{Photographs of recorded and identified fishes in the Yamuna river at Kalpi (Study Area)}

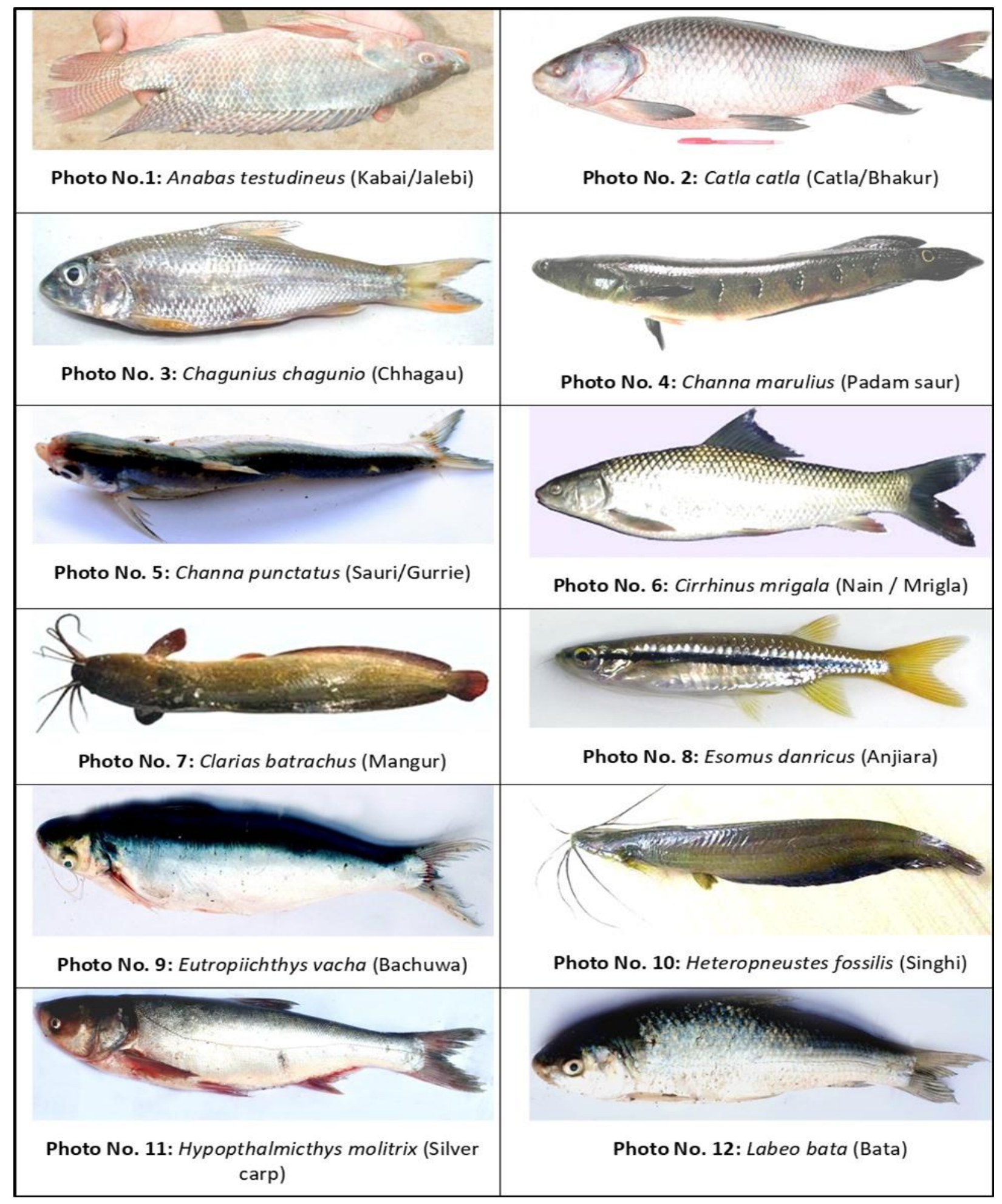




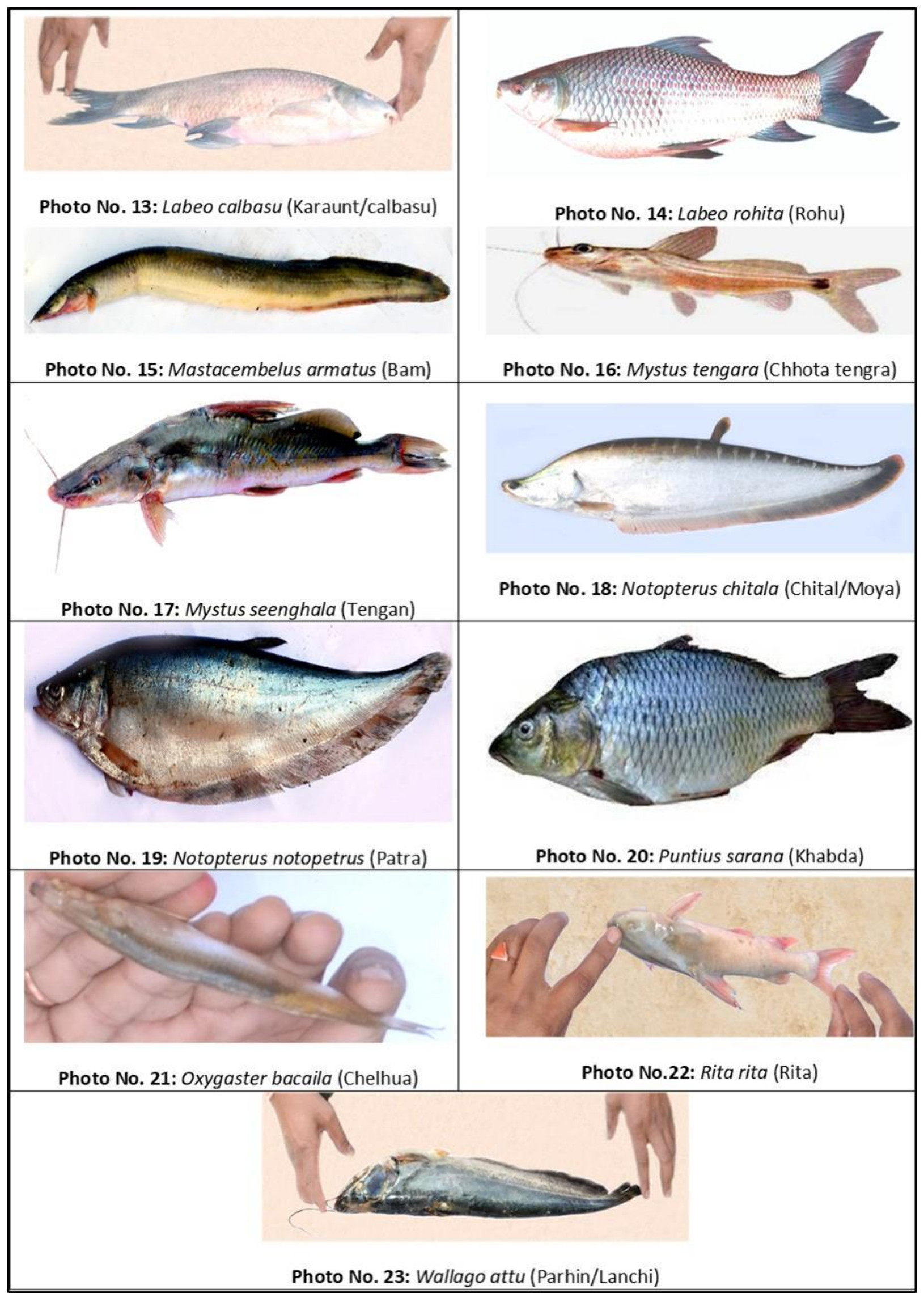




\section{Conclusion}

Survival and growth of fishes in the Yamuna river is depend totally upon its physicochemical parameters. Physicochemical parameters like W.T., $\mathrm{pH}$, Conductivity, T.D.S., T.H., T.A., $\mathrm{Cl}, \mathrm{SO}_{4}, \mathrm{PO}_{4}, \mathrm{NO}_{3}$, D.O., were found always under the limit while Turbidity, B.O.D. and C.O.D. found mostly suitable for fish survival and good reproduction rate. Thus physicochemical quality of the Yamuna water in study area was fit for fish diversity, growth, reproduction and fish cultivation during study period. To improve water quality of the river, stop pollution creating activities like throwing of solid wastes and garbage, discharge of municipal sewage, discharge of industrial effluents, mass bathing, cattle bathing, immersion of idols, cremation of dead bodies in nearby areas and agricultural runoff. Periodic survey and follow up programme are also recommended to sustain pristine water quality of the holy river Yamuna.

\section{Compliance with ethical standards}

\section{Acknowledgments}

I am gratefully thanking to Dr. P. K. Khare Professor Dept. of Botany Maharaja Govt. Autonomous P.G. College Chhatarpur, M.P. for valuable guidance and support to this research work. I am also gratefully thanking to the Principal and Head of Department of Botany, Maharaja Government Autonomous P.G. College Chhatarpur, M.P. for providing lab facilities.

\section{Disclosure of conflict of interest:}

$\mathrm{Nil}$

\section{References}

[1] Mishra DN, Moza U. Changing scenario of fish and fishery of river Yamuna-part 2, Proceedings of the National Seminar, Changing Perspective of Inland Fisheries, Inland Fishery Society, India. 1997: 57-62.

[2] Mishra DN, Moza U. Changing scenario of fish and fishery of river Yamuna-part 1, Bull. Environmental science B. 1998; $1: 5-10$.

[3] Mishra DN, Moza U. Evaluation of fish and fishery resources in river Yamuna Part 1, Jou. of Indian Fish. Soci., India. 2001; 33(1): 93-99.

[4] Moza U, Mishra DN. Evaluation of fish biomass and community structure in the context of environmental modification in upper stretches of river Yamuna Part-2, Applied fisheries and Aqua culture. 2001; 1(1): 17-21.

[5] Sarkar UK, Pathak AK, Sinha RK, Shiva Kumar K, Pandian AK, Pandey A, Dubey VK, Lakra WS Fresh Water fish biodiversity in the river Ganga (India) changing pattern, threats and conservation perspective, Reviews in Fish Biology and Fisheries. 2011; 22: 251-72.

[6] Bhalerao SN. Study of Fish Diversity and Water Quality at Kasar Sai Dam, Hinjewadi, Pune, (M.S.) India, Int. Res. Jou. of Biological Sciences. 2012; 1(4): 51-55.

[7] Sharma AP, Das MK, Samanta S, Paul SK, Bhowmick C. The Ecology and Fishery Status of River Yamuna, Central Inland Fisheries Research Institute (CIFRI), Bulletin no. 2014; 184: 1-32.

[8] Joshi KD, Alam A, Jha DN, Shrivastava SK, Kumar V. Fish diversity, Composition and Invasion of Exotic Fishes in River Yamuna under altered water quality conditions, Indian Journal of Animal Sciences. 2016; 86(8): $957-963$.

[9] Kumar M, Khare PK, Chaurasia S, Singh R. Fish Diversity and their Limnological Status of River Yamuna at Kalpi, U.P., India, HYDRO NEPAL. 2016; 19: 57-62.

[10] Sharma AP, Das MK, Vass KK, Tyagi RK. Patterns of Fish Diversity, Community Structure and Ecological Integrity of River Yamuna, India, Aquatic Ecosystem Health \& Management. 2017; 20(1-2): 30-42.

[11] APHA Standard method for the estimation of water and waste water, 21st Ed., Washington DC. 2005.

[12] Trivedi RK, Goel PK. Chemical and Biological methods for water pollution Studies, Env. Publisher Karad, 2nd Ed, 415110, India. 1986.

[13] Talwar PK, Jhingran AG. Inland Fishes of India and Adjacent Countries, vol.2. A.A. Balkema, Rotterdam. 1991.

[14] Jayram KC. The fresh water fishes of the Indian Region, Narendra Publishing House, Delhi, $2010 ; 616$. 
[15] CPCB, Water quality status of Yamuna River (1999-2005). Central Pollution Control Board, Assessment and Development of River Basin Series, ADSORBS/41/2006-07.

[16] Khanna DR, Bhutani R. Laboratory manual of water and waste water analysis, Dayal Publishing House, New Delhi. 2007; $1-184$.

[17] Khanna DR, Bhutani R, Ruhela M. Fish diversity and their limnological status of Ganga river system in foot hills of Garhwal Himalaya, Uttarakhand, India, J. Enviro. Res. Develop. 2013; 7(4): 1374-1380.

[18] Alikunhi KH. Fish culture in India, Fm, Bull. Indian Coun. Agri. Res. 1957; $20: 144$.

[19] Grover SP, Gupta SK. Fish and fishery of Banda district (U.P.), Proceedings of the Natural Academy of sciences, India. 1977; 47(4): 204-217.

[20] $\operatorname{IIT}_{(\mathrm{s})}$ Floral and Faunal Diversity in Yamuna River (Yamunotri to Allahabad) under the GRB EMP (Ganga River Basin Environmental Management Plan). 2012; 1-48. 